\title{
Ostracods as freshwater pollution indicators: a case study from the Ouseburn, a polluted urban catchment (Tyneside, NE England)
}

\author{
IAN BOOMER ${ }^{1,2} \&$ FRANCES ATTWOOD ${ }^{1,3}$ \\ ${ }^{1}$ Department of Geography, University of Newcastle, Newcastle NE1 7RU, UK \\ ${ }^{2}$ Current address: School of Geography, Earth and Environmental Sciences, University of Birmingham, Edgbaston, Birmingham B15 2TT, UK \\ (e-mail i.boomer@bham.ac.uk) \\ ${ }^{3}$ Current address: The Environment Agency, Rivers House, St Mellons, Cardiff, UK
}

\begin{abstract}
The relationship between ostracod occurrence and water quality is investigated in the Ouseburn (Newcastle upon Tyne, NE England) in both a spatial and temporal context. For the first time, ostracod assemblages are used alongside traditional biological water quality indices. Physico-chemical parameters of the water are used in conjunction with standard macro-invertebrate-based biological indices (BMWP, ASPT) to assess general water quality. This is also the first detailed study of ostracod occurrence within a small urban catchment. Ostracod, macro-invertebrate and environmental samples were taken during the summer of 2001, with a small number of late autumn replicates taken to characterize the impact of known pollution events. The pollutants encountered in this study are primarily organic in nature and include sewage, agricultural sources (such as slurry) and de-icer runoff from the local airport. The head-water and tributaries are generally characterized by good water quality despite a number of pollution events recorded during the study. Ostracod diversity and abundance, although often low, support the evidence from the traditional methods of water quality assessment, both of which decrease downstream. An inverse relationship observed between ostracod abundance and macro-invertebrate indices suggests that relatively clean-water macro-invertebrate assemblages out-compete the ostracods or may be preying upon them. J. Micropalaeontol. 26(2): 117-125, October 2007.
\end{abstract}

KEYWORDS: Ostracoda, Ouseburn, pollution, biological indicators, macro-invertebrates

\section{INTRODUCTION}

Biological indicators are useful measures of pollution loading in river systems because they respond to intermittent pollution events that might flush-through relatively quickly but may be missed by subsequent chemical sampling when the pollutant has passed through the system; they may also respond to pollutants which are not picked up by routine chemical monitoring. Biological organisms provide an indication of the pollutant's direct effect on the environment and are differentially sensitive to pollutants of various types, while different species and groups of organisms also react at different rates. Macro-invertebrates, generally $>2 \mathrm{~mm}$ in length (e.g. gastropods, chironomids and the aquatic larval or adult stages of various insects), in particular are traditionally used as biological indicators to provide a qualitative and/or quantitative indication of water quality by their presence/absence and abundance (Mason, 1996). Microinvertebrates and their fossils are rarely employed as pollutant indicators in isolation but the widespread occurrence and often great numerical abundance of ostracods in freshwater suggests that such an application may have great potential. Foraminifera have also proven to be useful indicators, particularly of organic pollution, in coastal waters (Alve, 1995; Samir, 2000).

The BMWP (Biological Monitoring Working Party) score has become one of the most commonly used methods of biologically classifying water quality in the UK (similar scoring schemes are available in other countries). The BMWP score is based upon the occurrence of key identifier groups of macro-invertebrates (usually at family level) each of which score from 1-10, with the highest scores indicating taxa that tolerate only the cleanest water. The scoring system is agglomerative within a sample, i.e. for each taxon present, their score is added to the total for that sample. The score is added only once, irrespective of how abundant or dominant the taxon may be in that sample. The ASPT (Average Score Per Taxon), derived from the BMWP score, is considered a more reliable indicator of environmental conditions as it is less sensitive to seasonal variation and sampling effort (Armitage et al., 1983). To derive the ASPT, the BMWP score is divided by the number of scoring taxa in that sample.

Ostracods (calcareous-shelled, bivalved micro-crustacea) are not included within the BMWP system since, as a group, they are known to tolerate a wide range of environments and, due to their size, have traditionally been considered unsuitable for rapid identification at genus and species level by the nonspecialist. Recent taxonomic advances (e.g. Meisch, 2000) have helped overcome many of the identification problems in European freshwater ostracods. One important advantage that the ostracods possess over most aquatic invertebrates is that their calcareous carapaces are often preserved after death thus leaving a potential record of their response to changing water quality.

Biological water quality scores are commonly used in conjunction with chemical indices. The most common chemical parameters include Biological Oxygen Demand (BOD), Ammonia (as ammoniacal nitrogen) and Total Organic Carbon (TOC) content. Together these indicate the chemical quality of the river and, in particular, the ability of it to support a diverse flora and fauna. The aim of this paper is to compare ostracod abundance and species occurrence with traditional biological and chemical water quality indices in a river that has been monitored for some time and is known to periodically suffer significant levels of organic pollution. 


\section{OSTRACODA AS POLLUTION INDICATORS}

The value of ostracods in palaeoenvironmental reconstruction has increased greatly in recent years. This has been helped by advances in analytical techniques, particularly trace-element and stable-isotope analyses. The establishment of local and regional databases detailing the modern ecology of both marine and non-marine Ostracoda (e.g. Forester et al., 2005; Horne et al., 1998) has transformed them from qualitative to quantitative indicators of past environments, although the modern ecology of many species still remains poorly understood. However, much of this work remains qualitative to semi-quantitative and, at present, there are no recognized indicator ostracod taxa suitable for the quantitative reconstruction of past nutrient loads or other organic pollutants in freshwater to coastal ecosystems despite their often ubiquitous occurrence in many of these environments.

\section{Case studies}

While some ostracod species are sensitive to the most subtle changes in their environment (stenotopic), others are capable of withstanding a wide range of conditions, even to the extent of inhabiting heavily polluted sites (eurytopic), but the exact tolerance limits have not yet been determined. Previous studies have examined ostracods from polluted waters in both freshwater and marine environments. For example the response of the Ostracoda to one of the most drastic 'pollution' events of the twentieth century, the salinization and chemical contamination of the Aral Sea, was outlined by Boomer (1993) and Boomer et al. (1996). Other examples include the work of Mezquita $\mathrm{et} \mathrm{al}$. (1999), who investigated ostracod population changes over a six-month period in the polluted River Magre (Valencia, SE Spain), an area impacted both by industrial and domestic waste waters. Spatial changes in ostracod populations were observed downstream of sewage inputs, with certain species gradually replacing others as water quality changed. The most heavily polluted sites contained no living ostracods with some species re-appearing away from the pollution source towards a 'recovery' zone. Mezquita et al. (1999) recorded detailed water chemistry changes throughout the study (including sulphates, chlorides, nitrates, nitrites), together with the regionally adjusted Iberian variant of the BMWP score. They outlined the importance of multivariate analyses when combining large environmental and chemical datasets. A further example of ostracod applied to pollution studies from Spain is given by Ruiz et al. (2000).

Rosenfeld et al. (2000) studied ostracods in the Harod River, northern Israel and suggested that they were potentially important indicators of minor pollution events not detected by chemical analysis. Both of these studies indicated that, despite their generally widespread occurrence in freshwater ecosystems, ostracods were absent from rivers with particularly poor water quality.

In the west Pacific a number of workers have investigated the possible relationship between ostracod distribution and pollution (particularly industrial/heavy metals) in coastal waters. Bodergat \& Ikeya (1988) suggested that pollution levels may be important in understanding the distribution of ostracods on the Pacific coast of central Japan. Schornikov (2000a) investigated the pollution sensitivity of non-marine, brackish and marine

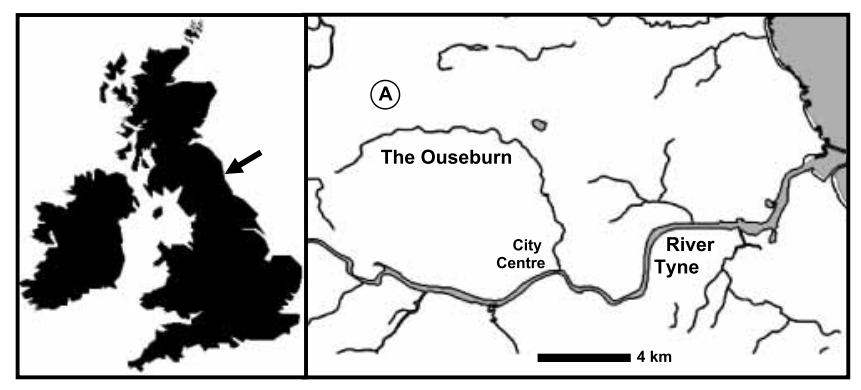

Fig. 1. Location map of the Ouseburn, NE England.

ostracods along the Korean coastline; however, that work did not include any quantitative analysis or details of the pollutants. In another paper Schornikov (2000b) outlined briefly the impact of anthropogenic pollutants on the marginal marine ostracods of the Vladivostok Port area with living specimens absent from the most heavily polluted, nearshore environments. Yasuhara et al. (2003) undertook a similar study investigating the impacts of anthropogenic pollution on the ostracod assemblages of Hiroshima Bay, Japan, over the last 100 years. Their quantitative results showed that increasing pollution had a detrimental effect on ostracod abundance and diversity but again noted that some local species, in this case Bicornucythere bisanensis, are tolerant of such changes. Yasuhara et al. (2003) showed that the relative proportion of $B$. bisanensis and a particularly intolerant species (Callistocythere alata) could be used as an index of pollution in this area.

In a number of recent papers the effects of sewage pollution on coastal ostracod faunas have been investigated by Eagar (1999) in New Zealand and a Pacific atoll (Eagar, 2000). These studies have shown that although increasing levels of pollution result in reduced ostracod abundance and diversity, some species are capable of withstanding relatively high levels of organic loading.

In summary, the few papers published to date on the pollution tolerance of ostracods indicate that with increasing levels of pollution, ostracod diversity decreases, usually to only one or two generalist species which may occur in great abundance. This study investigates, albeit from a relatively small dataset, the relationship between ostracod abundance/diversity and water quality and the possible pollution tolerance of the most abundant species in the Ouseburn, northeast England.

\section{URBAN POLLUTION IN THE OUSEBURN}

The Ouseburn is a small urban river that joins the north bank of the River Tyne at Byker, in Newcastle (Fig. 1, National Grid Ref. NZ 254672); its physical attributes are outlined in Table 1. The water quality of the Ouseburn is important for biological, environmental, health and amenity reasons. The main influences upon river water quality in this catchment include urban wastewater such as sewage and surface runoff from Combined Sewer Overflows (CSOs), Cross Connected Sewers (CCSs; Baker, 2001), transport-related waste (Turnbull \& Bevan, 1994, 1995) and industrial effluents. Some of these contaminants will be toxic, others nutrient-polluting, all of which may increase suspended solid levels, smothering the river bed or elevating the biological oxygen demand (BOD) on the ecosystem. At times of high rainfall the sewerage system is often overloaded and will 
Length $(\mathrm{km})$

Catchment area $\left(\mathrm{km}^{2}\right) \quad 62.5$

Highest point (m above OD) 145

Gradient

Source (Callerton)

Confluence with Tyne (Byker)

Tidal section $(1 \mathrm{~km})$

Geology
$1: 101$

NZ 17646849

NZ 26456413

NZ 2645 6413-NZ 26276456

Coal measures of Carboniferous age, overlain by boulder clay up to $30 \mathrm{~m}$ thick

Table 1. Descriptive properties of the Ouseburn and catchment.

discharge raw or partially treated sewage into the river, exerting a high BOD, decreasing the dissolved oxygen (DO), increasing suspended solids and temperature whilst introducing pathogens and bacteria into the river (Seager \& Abrahams, 1990; Davis et al., 1995).

Despite these periodic impacts, long-term monthly monitoring of the BOD, ammonia and DO by the Environment Agency indicate the river quality to be 'fairly good' (following their General Quality Assessment scheme) from the source to the Great North Road (Fig. 2); after this point the quality declines
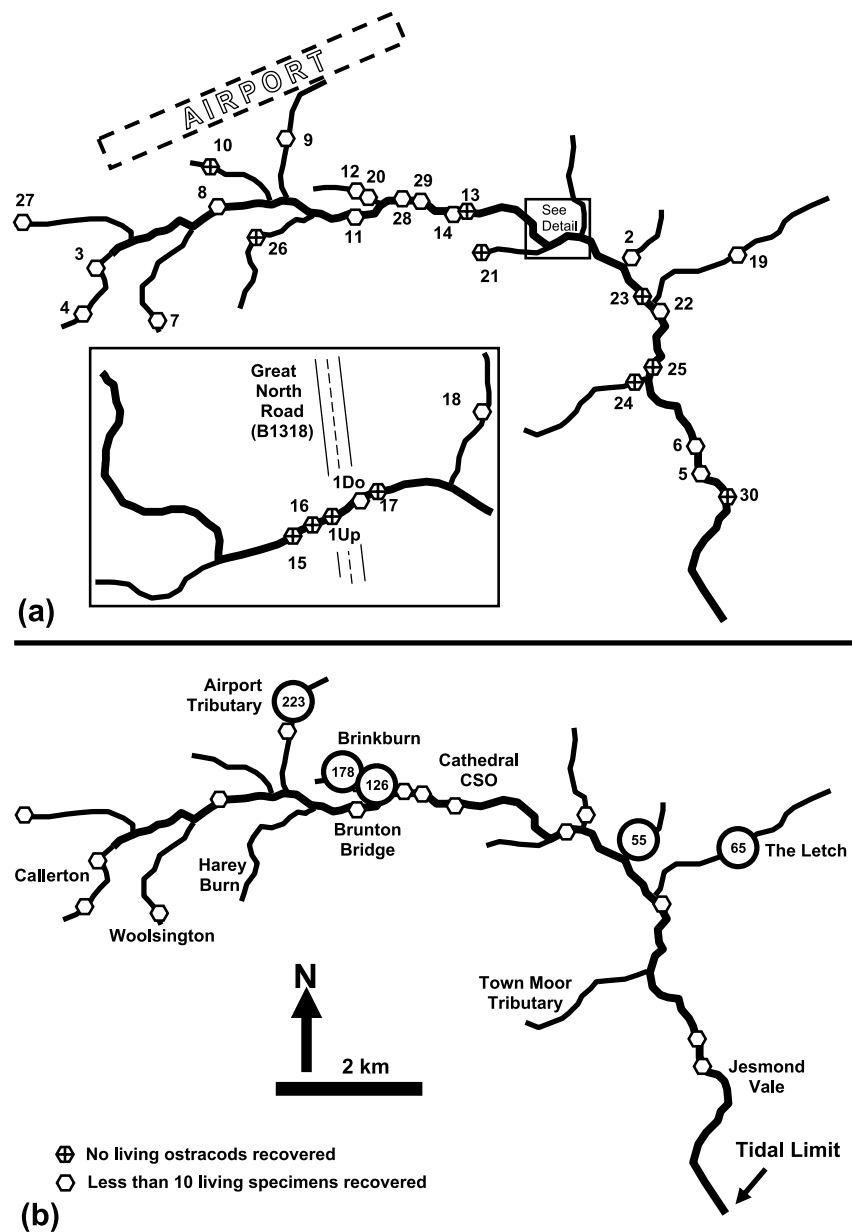

Fig. 2. (a) Location of sample sites on the Ouseburn; (b) indicating ostracod abundance and location of barren samples in study. Note that site 26 was sampled only in September and November 2001; it was barren on both occasions.

to 'fair' until it reaches the tidal limit, indicating a greater impact on the lower reaches of the catchment. Despite the severe but short-lived pollution events, water quality indicators suggest relatively good conditions within the catchment. The relatively poor biological scores, however, reflect the influence of those deleterious periodic events.

Following cold-weather periods, transport-related de-icers and other transport-sourced pollutants, such as salt, enter the river. An important contributor to the poor water quality of the Ouseburn is the local airport (Fig. 2). De-icer runoff into the airport tributary has a profound effect on the river during the autumn and winter period. Urea was used as a de-icer on the runway area until 1996, when it was replaced by propylene glycol that exerts a very high BOD on the river (Corsi et al., 2001). Despite the introduction of storage lagoons as pollution reduction measures in 2001, there has been a number of periodic failures subsequently (Turnbull \& Bevan, 1995). The region is also known to suffer from the emergence of acidic mine waters at the surface, which commonly find their way into surface drainage systems (Banks et al., 1997). Although these are known to cause localized, but significant, environmental problems in the region (Younger, 1995), they are thought to be of limited extent within the Ouseburn catchment.

\section{SAMPLING AND ANALYTICAL METHODS}

The main objective of this work is to investigate the influence of organic pollutants on ostracod diversity and distribution of species in the Ouseburn in conjunction with traditional water quality indices. The main period of sampling was undertaken between June and August 2001, although a small number of additional and replicate samples were recovered in September, October and November, mainly to focus on the effects of known pollution events. A total of 52 samples were collected from 31 sites (Fig. 2a). Of these, 20 samples from 18 sites yielded living ostracods (Fig. 2b). At each site a series of environmental variables was recorded in the field and water samples taken for laboratory analysis. A control ostracod sample was taken from a slow-flowing tributary of the Ouseburn (Site 19) with no known pollutant inputs. The control site is known to maintain consistently high water quality and good macrophyte coverage. Such habitats are known to support relatively diverse ostracod assemblages and the site was chosen as the optimum conditions for ostracods within this catchment. The environmental variables and records of living ostracods recovered at each site in the study are detailed in Table 2.

Replicate samples that yielded ostracods were taken from two sites ( 9 and 12) on an opportunistic basis shortly after pollution events were identified by the local Environment Agency office. Both sites are located close to Newcastle Airport and may have suffered release of de-icer material from there; the replicates are identified as $9 \mathrm{R}$ and $12 \mathrm{R}$.

Separate macro-invertebrate 'kick-samples' (see below) and ostracod samples were taken at each site (sites numbered 1-30). Samples specifically taken for ostracods were designed to sample as many habitats as possible at a given location on the river. In most cases samples will include material from more than one sweep through the substrate and/or macrophytes. Where possible, samples included dredges through both coarsegrained (sand-pebble-cobble) and fine-grained substrates 


\begin{tabular}{|c|c|c|c|c|c|c|c|c|c|c|c|c|c|c|c|c|c|c|c|c|c|c|c|c|c|}
\hline Sample & Date (2001) & 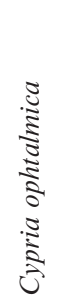 & 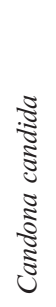 & 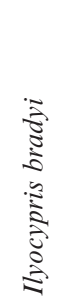 & 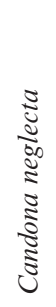 & 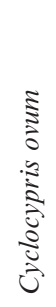 & 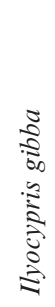 & 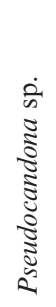 & 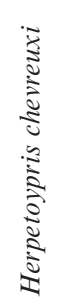 & 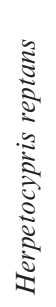 & 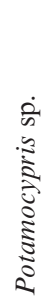 & 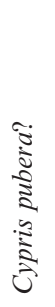 & 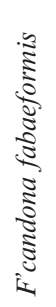 & 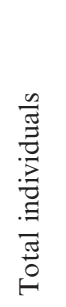 & 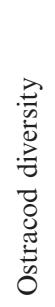 & $\frac{\pi}{2}$ & 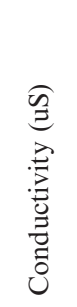 & $\begin{array}{l}0 \\
0 \\
0 \\
\stackrel{0}{0} \\
\stackrel{0}{\bullet}\end{array}$ & 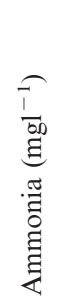 & 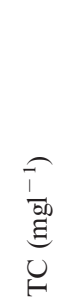 & 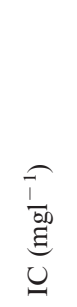 & 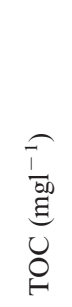 & 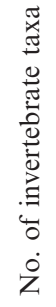 & 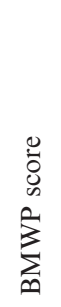 & 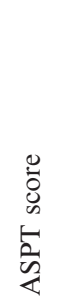 \\
\hline 1 & 26 June & & & & & & & & & & & 1 & & 1 & 1 & 7.88 & 988 & 16.9 & 0.3 & 61.3 & 55.3 & 5.9 & 6 & 16 & 2.7 \\
\hline 2 & 26 June & 5 & 30 & 1 & 1 & 20 & & & & 2 & & & & 59 & 6 & 8.15 & 629 & 17.4 & 0.3 & 45.2 & 32.2 & 13.0 & 9 & 39 & 4.3 \\
\hline 3 & 3 July & & & & & & & 1 & & & & & & 1 & 1 & 7.79 & 1273 & 16.0 & 0.1 & 44.8 & 40.8 & 3.9 & 9 & 43 & 4.8 \\
\hline 4 & 3 July & 1 & & & & 2 & & 2 & & & & & & 5 & 3 & 7.61 & 1372 & 14.3 & 0.2 & 45.4 & 42.0 & 3.4 & 10 & 43 & 4.3 \\
\hline 5 & 10 July & & & & & & & & & & & 1 & & 1 & 1 & 8.20 & 863 & 15.7 & 0.0 & 8.2 & - & - & - & - & - \\
\hline 6 & 10 July & & & & & 2 & & & & & & & & 2 & 1 & 7.97 & 909 & 14.9 & 0.1 & 53.7 & 45.3 & 8.3 & - & - & - \\
\hline 11 & 19 July & 2 & & & 3 & 2 & & & & & & & & 7 & 3 & 8.60 & 1177 & 13.3 & 0.1 & 49.6 & 40.5 & 9.1 & 10 & 47 & 4.7 \\
\hline 12 & 19 July & 3 & 45 & 130 & & & & & & & & & & 178 & 3 & 8.10 & 876 & 11.0 & - & 76.7 & 73.8 & 2.9 & 7 & 33 & 4.7 \\
\hline $12 \mathrm{R}$ & 16 November & 15 & 43 & 4 & & & & & & & & & & 62 & 3 & 7.90 & 627 & 8.0 & 0.0 & 58.2 & 52.1 & 6.1 & 11 & 49 & 4.5 \\
\hline 14 & 19 July & & & & & 2 & & & & & & & & 2 & 1 & 7.90 & 817 & 12.6 & 0.1 & 52.4 & 44.0 & 8.4 & 7 & 18 & 2.6 \\
\hline 18 & 23 July & & & & 3 & & & & & & & & & 3 & 1 & 7.84 & 1297 & 15.4 & 0.0 & 64.0 & 56.6 & 7.5 & 9 & 33 & 3.7 \\
\hline 19 & 24 July & & & & 28 & 10 & 20 & 6 & 7 & 5 & & & & 76 & 6 & 7.52 & 966 & 17.0 & 0.1 & 61.9 & 51.7 & 10.2 & 11 & 43 & 3.9 \\
\hline 20 & 30 July & 79 & 20 & & 13 & 1 & 13 & & & & & & & 126 & 5 & 8.28 & 880 & 13.8 & 0.0 & 77.3 & 67.1 & 10.2 & 8 & 30 & 3.8 \\
\hline 22 & 30 July & & & & & 1 & & & & & & & & 1 & 1 & 8.08 & 738 & 17.1 & 0.2 & 52.9 & 39.4 & 13.5 & 6 & 19 & 3.2 \\
\hline 27 & 14 August & & & & & & & & & & 2 & & & 2 & 1 & 7.90 & 704 & 15.4 & 0.0 & 75.5 & 69.7 & 5.8 & - & - & - \\
\hline 28 & 14 August & 1 & & & & & 1 & & & & & & & 2 & 2 & 7.94 & 884 & 18.0 & 0.1 & 64.5 & 55.4 & 9.1 & 9 & 37 & 4.1 \\
\hline
\end{tabular}

ASPT, Average Score Per Taxon; BMWP, Biological Monitoring Working Party

Table 2. Details of physico-chemical parameters and ostracod species abundance in samples containing living ostracods.

(clay-silt-sand) as well as through macrophytes and organicrich sediments, thereby covering all habitats. The sampling was therefore designed to be independent of substrate (otherwise known to be an important ecological control on ostracod distribution) and should reflect water quality more directly. The kick-samples were investigated in the laboratory, from which, additional ostracods were often recovered.

The ostracod samples were collected using two nested sieves at $2000 \mu \mathrm{m}$ and $180 \mu \mathrm{m}$. Plant and sediment was washed through the larger sieve and retained on the smaller, lower sieve, the process continued for at least two minutes until all immediate habitats had been sampled. When possible, samples were examined and sorted for live individuals within a day of collection and the picked specimens fixed in ethanol. Otherwise, samples were fixed with ethanol in the field and sorted at a later date. All samples were totally picked, single valves were picked and counted but not further considered within this study as they could not be considered with certainty as being in situ. Many sites were sampled only once (during the summer), while others were sampled as many as three times after known pollution events.

Macro-invertebrate samples were collected using the standard BMWP 'kick-sampling' technique (Mason, 1996), where the net is held downstream of the sampler and the upstream substrate is agitated for three minutes, moving back and forth across the channel. The disturbed macro-invertebrates 'flow' into the $1 \mathrm{~mm}$ mesh net. After three minutes the sample is collected and invertebrates picked within one-two days. Samples were stored in ethanol and studied using standard identification keys (e.g. Croft, 1986).

Water $\mathrm{pH}$, conductivity and temperature were determined in the field using a hand-held Myron 6P Ultrameter. Separate water samples were taken in acid-cleaned $50 \mathrm{ml}$ polyethylene bottles, refrigerated and analysed for ammonia using a Hannah Ammonia Meter (HI 93715) calculated as ammoniacal nitrate. The TOC, total carbon (TC) and inorganic carbon (IC) were determined using a Shimadzu 5000 TOC analyser.

Ammonia and TOC levels are standard measurements of water quality. According to the UK Environment Agency criteria (Environment Agency, 2006), ammonia concentrations of $>2.5 \mathrm{mgN}^{-1}$ are generally taken to indicate 'poor' or 'bad' water quality. Although the EA do not include TOC values in the standard assessment of water quality, most investigators consider concentrations in excess of $10 \mathrm{mg} \mathrm{l}^{-1}$ to be indicative of anthropogenic pollution.

\section{RESULTS}

\section{Water quality}

The field and laboratory results for water quality are detailed in Table 2. Conductivity was generally between $800 \mu \mathrm{S}$ and $1200 \mu \mathrm{S}$ (total range 564-1297 $\mu \mathrm{S}$ ) and $\mathrm{pH}$ within the range 7.6-8.3 (total range $7.52-8.60)$. These are weakly alkaline, oligohaline waters that should not provide any barrier to the occurrence of ostracods. TOC was usually within $4-10 \mathrm{mg}^{-1}$ (total range 3.4-15.3) and ammonia $1-3 \mathrm{mg} \mathrm{l}^{-1}$ (total range $<0.01-$ 

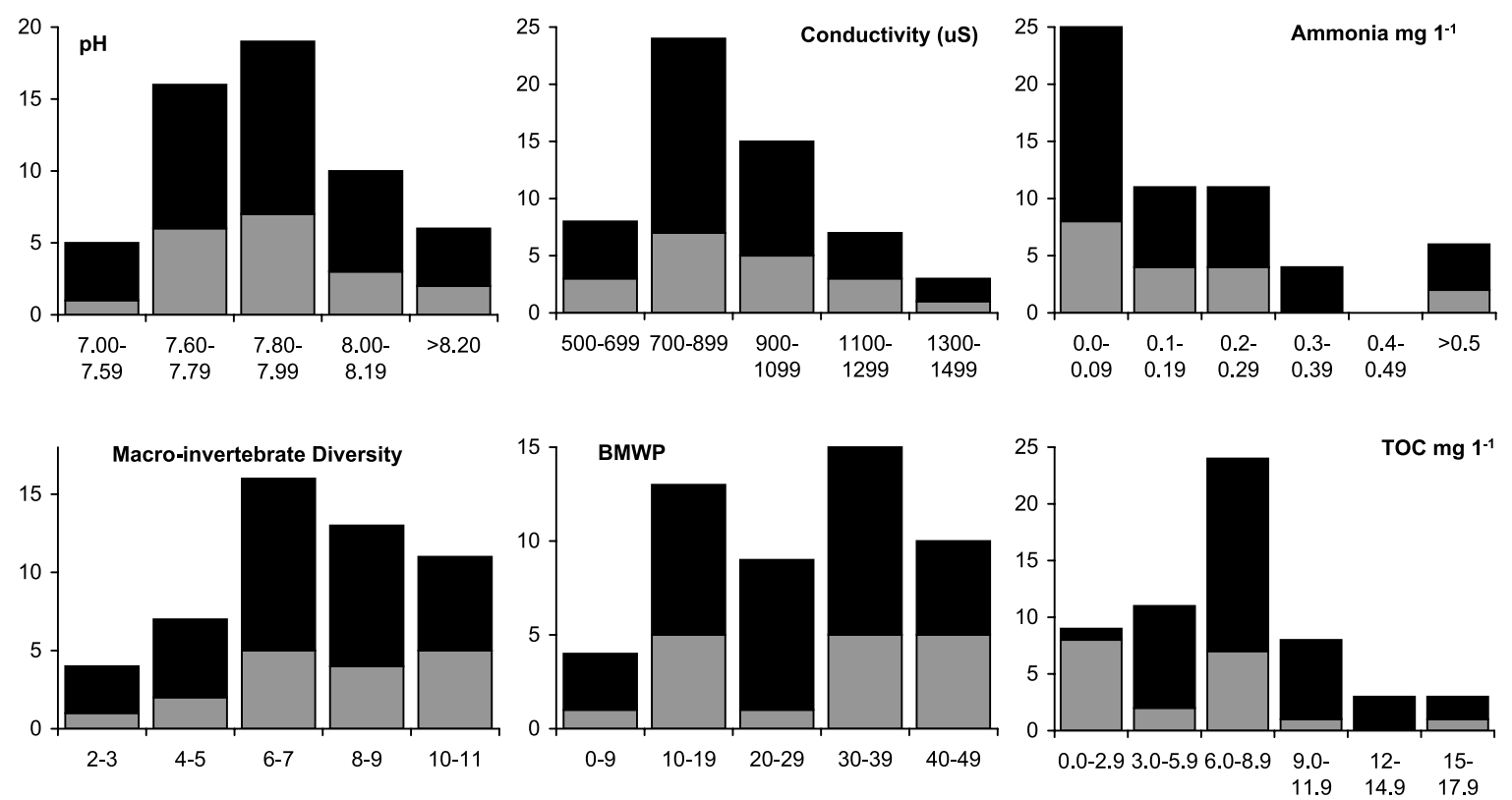

Fig. 3. Histograms showing the number of samples recorded (y-axis) across the total range of six key environmental indicators (black) and the number of samples containing living ostracods within those ranges (grey).
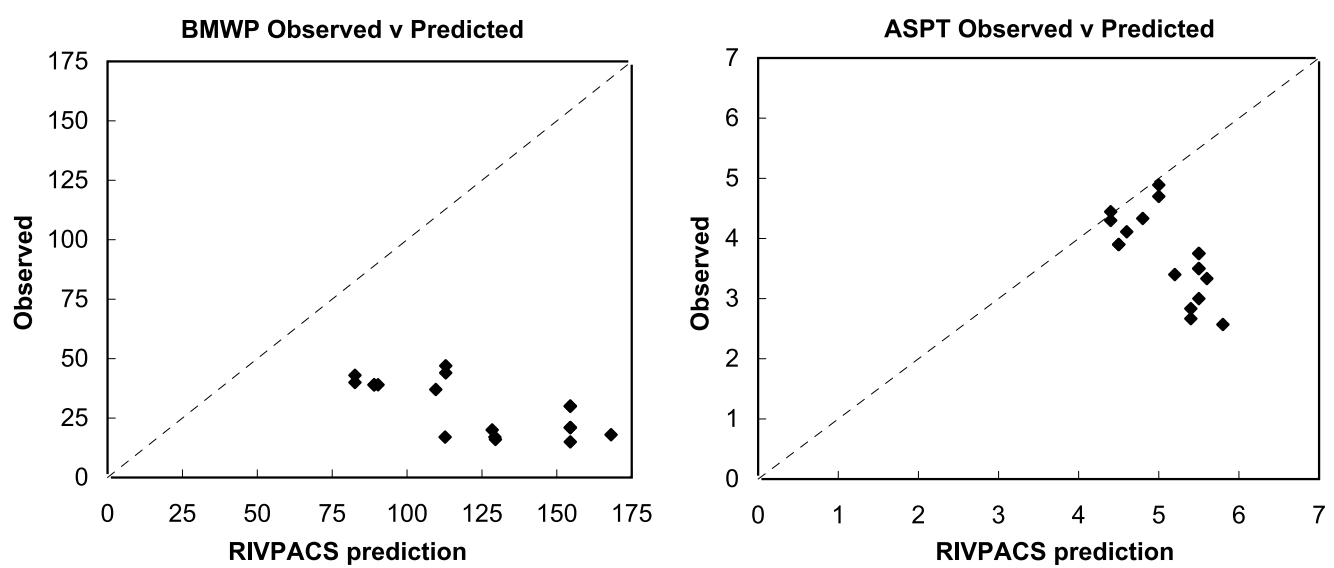

Fig. 4. Comparison of observed BMWP and ASPT scores against RIVPACS predicted scores. In both cases the observed scores are lower than expected for the Ouseburn based on the predicted RIVPACS score.

$0.85 \mathrm{mg}^{-1}$, plus one pollution event recorded at $19.5 \mathrm{mg}^{-1}$ ). The distribution of ostracod samples within the environmental dataset is illustrated in Figure 3. The proportion of ostracodbearing and barren samples does not significantly alter for the conductivity and $\mathrm{pH}$ data. As might be expected, there is generally a decreasing proportion of ostracod-bearing samples with increasing levels of TOC and ammonia, conversely as the macro-invertebrate indices increase, so too does the abundance of ostracods within this dataset, see below.

Biological indices (BMWP, 14-49; ASPT, 2.6-4.8), also shown on Table 2, are lower than would be expected if the river was in pristine condition. This has been determined by comparing the observed scores with those predicted by the RIVPACS programme (Wright et al., 1998). The relatively low observed values (Fig. 4) indicate that despite the apparently good water quality observed throughout much of the study, biological evidence reflects poor long-term water quality resulting from periodic pollution events. Figure 3 details the total range for the key environmental variables recorded as well as indication of the occurrence of ostracod-bearing samples within those ranges.

\section{Ostracoda}

Fifteen different species of ostracods were found in 20 samples (including two replicates) from 31 sites, with abundances varying from 1 to 223 living individuals (Table 2), comprising a total of 774 individuals. The study is dominated by five species that together constitute $92 \%$ of the total. The six least common species all occurred as less than ten individuals, three of which are represented by only one or two specimens. The five most abundant species are Cypria ophtalmica (44\%), Candona candida (18\%), Ilyocypris bradyi (18\%), Cyclocypris ovum $(6 \%)$ and Candona neglecta $(6 \%)$. These species are characteristically eurytopic, with a European to cosmopolitan distribution. 
(a) BMWP v

Invertebrate Diversity

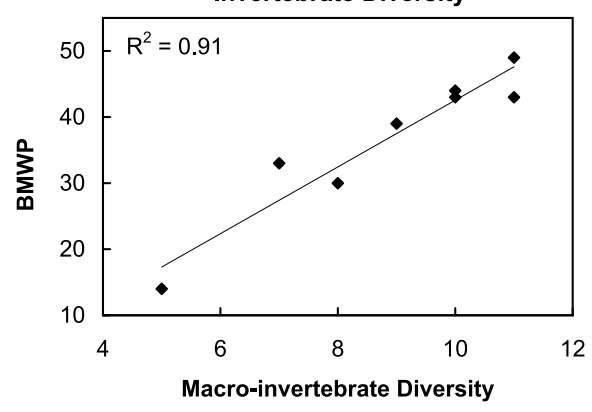

(c) Ostracod Abundance $v$ Invertebrate Diversity

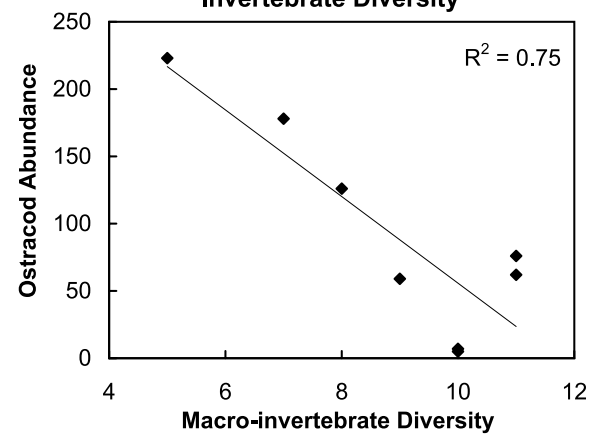

(b) ASPT v BMWP

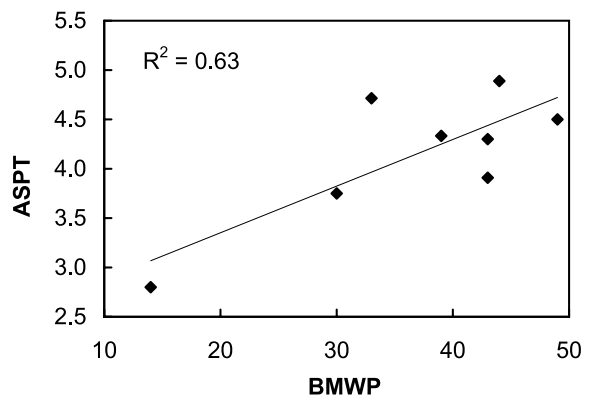

(d) Ostracod Abundance v BMWP

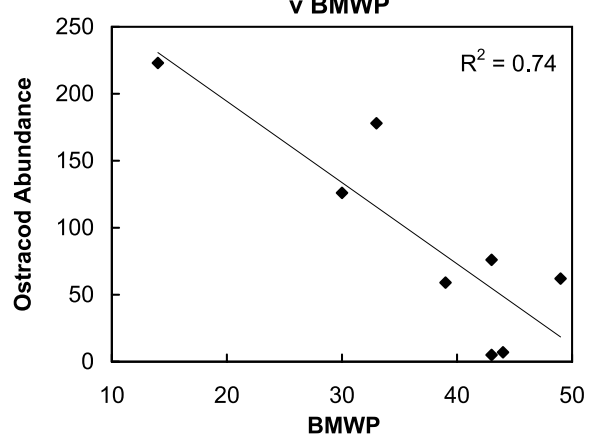

Fig. 5. Four strongest correlations within and between the macro-invertebrate and ostracod data. Note that 'Invertebrate Diversity' is for scoring taxa at Family level.

Cypria ophtalmica and Cyclocypris ovum, both nectobenthonic active swimmers, were the most common species at sites 9 and 10, respectively. The occurrence of these species in a range of polluted waters supports observations by a number of authors (e.g. Curry, 1999) that they tolerate wide ecological ranges. Meisch (2000) noted C. ophtalmica as being representative of a group of ostracods with a wide ecological tolerance which, he suggested, was probably due to its 'general purpose genotype'. C. ophtalmica was also noted by Meisch to be present in waters with high organic pollution. Both $C$. candida and $C$. neglecta are large benthic species, both known to withstand slightly elevated salinities but generally restricted to cool temperate water bodies.

Most of these species (the exception being I. bradyi) are known to possess desiccation-resistant stages at some point in their life cycles, while all are known to inhabit interstitial habitats that may provide refugia during periods of poor water quality in the main steam channel. Both of these characteristics may help explain their appearance and success in waters that are periodically exposed to pollution, enabling the stream to be re-colonized swiftly after such events.

Ostracod abundance. Although it is difficult to make significant conclusions based on ostracod abundance alone, due to the different sampling strategies at each site, it is possible to make some broad-scale observations. Ostracod abundances were high (59-223) in samples 2, 9, 12,12R, 19 and 20; all of these sites are from relatively clean tributaries, excluding sample 9 which was taken from the airport tributary and was dominated by Cypria ophtalmica. This species is known to be particularly tolerant of high levels of organic pollution and was associated with relatively low BMWP and ASPT scores. Pollution from the airport is unlikely to be significant at the time of collection given that the sample was taken in June. Sample 12R, an autumn replicate taken after a known pollution event (probable de-icer discharge) in the Brinkburn, also adjacent to the airport, recorded a similar fauna to that of the summer sampling but with almost no Ilyocypris bradyi, indicating that this species may be intolerant of this pollutant.

Where present, ostracod abundance is generally lowest in the main river channel and upper river reaches (1-7 specimens), which could be a function of habitat (coarser bed-load) and the relatively higher flow regimes of the main channel or the cumulative (episodic) pollution suspected at these sites.

Cypria ophtalmica was found in particularly high abundances at site 9 during the summer period. Sample 9R, the autumn replicate, was taken shortly after the first heavy frost of the year which may have meant that the site was influenced by de-icing activities at the airport, although chemical analysis does not indicate runoff into the tributary at the time of collection. However, this does not prove that a runoff event did not occur, since chemical spot-sampling programmes are recognized as being likely to miss intermittent pollution pulses (Hazelton, 1998). Indeed the TOC values were approximately $35 \%$ lower than during the summer.

Figure 5 illustrates the most significant relationships $\left(\mathrm{R}^{2}>0.6\right)$ within and between the macro-invertebrate and ostracod data for the seven most abundant ostracod samples (>10 living specimens). There are no significant relationships between biological and environmental data. Notwithstanding the size of this 


\begin{tabular}{|c|c|c|c|c|c|c|c|c|c|c|c|}
\hline & & $\mathrm{pH}$ & $\begin{array}{l}\text { Cond. } \\
(\mu S)\end{array}$ & $\begin{array}{l}\text { Temp. } \\
\left({ }^{\circ} \mathrm{C}\right)\end{array}$ & $\begin{array}{l}\text { Ammonia } \\
\left(\mathrm{mgl}^{-1}\right)\end{array}$ & $\begin{array}{c}\mathrm{TC} \\
\left(\mathrm{mgl}^{-1}\right)\end{array}$ & $\begin{array}{c}\mathrm{IC} \\
\left(\mathrm{mgl}^{-1}\right)\end{array}$ & $\begin{array}{c}\text { TOC } \\
\left(\mathrm{mgl}^{-1}\right)\end{array}$ & $\begin{array}{l}\text { No. of } \\
\text { taxa }\end{array}$ & $\begin{array}{l}\text { BMWP } \\
\text { score }\end{array}$ & $\begin{array}{l}\text { ASPT } \\
\text { Score }\end{array}$ \\
\hline Samples with & (mean value) & 7.9 & 924 & 14.0 & 0.18 & 59.4 & 51.4 & 8.0 & 8.1 & 31.6 & 3.8 \\
\hline ostracods & (std dev.) & 0.3 & 233 & 3.1 & 0.21 & 13.5 & 13.0 & 3.4 & 2.0 & 11.8 & 0.7 \\
\hline \multirow[t]{2}{*}{ Barren samples } & (mean value) & 7.8 & 904 & 13.9 & 0.18 & 55.0 & 46.7 & 7.4 & 6.1 & 21.2 & 3.3 \\
\hline & (std dev.) & 0.4 & 323 & 3.3 & 0.19 & 11.9 & 10.7 & 2.3 & 2.3 & 10.2 & 0.9 \\
\hline
\end{tabular}

Table 3. Comparison of environmental variables between those samples with and those without ostracods.

relatively small dataset, there appears to be a strong negative correlation between macro-invertebrates scores and ostracod abundance. This may be due to a number of factors, competition pressures between the two groups, the larger macroinvertebrates possibly preying on the smaller ostracods or another physical or chemical characteristic not recognized from the sampling programme which favours one at the expense of the other. It would seem that in the absence of diverse 'predator' macro-invertebrates (low scoring assemblages are often dominated by grazers), the ostracods reach their greatest abundances.

Ostracod diversity. Ostracod diversity was recorded as the number of living species identified in each sample. Samples 2, 19 and 20 were the most diverse ostracod assemblages, with five to six species in each, 19 being the control site. These samples come from relatively clean tributaries, as suggested by the higher macro-invertebrate scores and low concentrations of chemical and organic pollution indicators. Upstream of several of these 'clean' sites are further shallow wetlands, with emergent macrophytes, providing sheltered, organic-rich quiet conditions that could provide refugia habitats acting as centres for re-colonization following adverse events.

The two replicate samples $9 \mathrm{R}$ and $12 \mathrm{R}$ are, not surprisingly, marked by cooler water temperatures than the summer samples and much lower conductivity, probably due to dilution from autumn/winter rainwater runoff. TOC was much lower at site 9 but higher at site 12 compared with the summer samples. This suggests that the pollution event at site 12 was still affecting water quality. Despite this, the BMWP score was higher, due mainly to the increase in the number of scoring taxa; however, the ASPT was slightly lower. There was little difference in the ostracod faunas between the summer and autumn replicates at site 12, apart from the marked decrease in abundance of $I$. bradyi as noted above. Site 9 yielded only two species in summer, down to one during the autumn collection with a marked reduction in abundance.

Despite retaining high macro-invertebrate scores, the autumn replicate at site 20 was devoid of ostracods, this is a marked change from the summer sample which yielded 126 specimens belonging to five species. Autumn replicates at sites 7 and 8 were barren and this was reflected in a decrease in macro-invertebrate scores, indicating water quality issues that had affected the whole stream community at this location. Sample 30 was barren during the summer and autumn, while sample 26 was barren during two collections in September and November; due to access restrictions it was not sampled during the summer period.

Summary. Ostracod diversity is low throughout the study (maximum six species). Of the 19 samples bearing live ostracods, nine included only a single ostracod species while three contained just two species. Ostracod diversity is lowest in samples taken in the downstream reaches of the main river; the highest diversities were recorded in the tributaries and the upper reaches of the Ouseburn, reflecting the cumulative effects of poor water quality downstream. Such low diversity, even in the control sample, makes it difficult to propose the ostracods as sensitive pollution indicators. However, it is clear that some species appear better adapted to poor water quality conditions than others.

The tributaries and headwaters have higher biological scores and generally higher ostracod diversity and abundances than the downstream main river sites. These findings correlate with the physico-chemical data, where chemical sampling has detected pollution pulses; however, the biological results are thought to represent a more representative long-term picture of the water quality of the river by reflecting intermittent pollutants not detected by the physico-chemical spot samples.

The occurrence or absence of ostracods cannot be correlated clearly with the environmental variables recorded. Table 3 shows little difference between those samples that yielded living ostracods and those that were barren. Since there are no marked differences between the two datasets, it must be assumed that the absence of ostracods is either due to natural factors (e.g. substrate, macrophyte coverage) or episodic pollution events not picked up by this sampling programme. The latter conclusion is supported by the observation that biological scores for the macro-invertebrates are also lower in the ostracod-barren samples.

\section{COMPARISON WITH OTHER STUDIES}

Mezquita et al. (1999) noted that Herpetocypris intermedia, Heterocypris incongruens, H. salina and occasionally Eucypris virens were more common at sites with moderate to high pollution. They also noted that Margalef (1953) had recorded $H$. incongruens as being tolerant of high organic matter content and low dissolved oxygen levels. H. incongruens is a successful, geographically widespread species more typical of temporary pools and wetlands rather than permanent waters due to its reproductive strategy (completing its life-cycle in a matter of weeks and laying desiccation-resistant eggs). The latter two species, although present, are very rare in the present study, the other three species are absent.

Ilyocypris bradyi and Candona neglecta were found at the cleanest sites as they were in Rosenfeld et al.'s (2000) study of the Harod River, where higher ostracod densities and diversities were found in the cleaner sites. Mezquita et al. (1999) found that ostracods were very scarce at polluted sites, in line with the lowest BMWP scores and low dissolved oxygen, again supported by the observations in the present study. 


\section{CONCLUSIONS}

The study involved widespread sampling over a small urban catchment, with a view to determining the relationship between ostracod abundance and diversity in relation to possible pollution impacts. Traditional water quality assessment methods demonstrate a broad decrease in water quality downstream as the catchment becomes increasingly urbanized. The results of the ostracod study indicate that the Ouseburn catchment is dominated by a few species, with more than $90 \%$ of all ostracods recovered belonging to just five species. The most abundant species are generally of cosmopolitan distribution and one of them, Cypria ophtalmica, now appears to be established as being tolerant of high organic pollution; Cyclocypris ovum appears to be moderately tolerant of organic pollution and Ilyocypris bradyi less tolerant of poor water quality. Of the 19 samples bearing live ostracods, only seven of them contained more than ten specimens. This would indicate that ostracods are relatively scarce within the catchment but it is difficult to prove whether this is a natural distribution or to what degree it has been driven by periodic pollution events. Given the high abundance of some species at sites known to suffer periodic adverse events, it is assumed that other, natural factors are controlling their distribution in this river.

As with previous studies it is shown that poor water quality results in either the absence of ostracods or the dominance of one or two specialized/generalist species, sometimes in great abundance. The interpretation of data from polluted rivers is limited to some extent by incomplete knowledge of ostracod occurrence, relative and absolute abundance in clean or relatively pristine habitats. Further work on interstitial faunas within rivers, i.e. within the bedload, is required to understand the possible role of these habitats as refugia during times of adverse environmental conditions.

\section{ACKNOWLEDGEMENTS}

The authors thank Dr Andy Baker (University of Birmingham) for reading an earlier draft of this manuscript and providing environmental data, Martin Charlton (National University of Ireland, Maynooth) for assistance with data analysis and Pat Johnson (University of Newcastle) for TOC analysis. Roger Inverarity, Nick Diggle and Vicki Warren (Environment Agency, Newcastle) are thanked for discussion and supplying data. Finally, thanks go to Watts Stelling, Matthew Wade and Hannah Durling for field assistance.

\section{Manuscript received 3 July 2006 Manuscript accepted 12 April 2007}

\section{REFERENCES}

Alve, E. 1995. Benthic foraminiferal responses to estuarine pollution; a review. Journal of Foraminiferal Research, 25(3): 190-203.

Armitage, P.D., Moss, D., Wright, J. \& Furse, M.T. 1983. The Performance of a new biological water quality score based on macroinvertebrates over a wide range of unpolluted running-water sites. Water Research, 17: 333-347.

Baker, A. 2001. Fluorescence excitation-emission matrix characterization of some sewage-impacted rivers. Environmental Science and Technology, 35: 948-953.

Banks, D., Younger, P.L., Arnesen, R.T., Iversen, E.R. \& Banks, S.B. 1997. Mine-water chemistry: the good, the bad and the ugly. Environmental Geology, 32: 157-174.
Bodergat, A.-M. \& Ikeya, N. 1988. Distribution of recent Ostracoda in Ise and Mikawa bays, Pacific coast of central Japan. In: Hanai, T., Ikeya, N. \& Ishizaki, K. (Eds), Evolutionary Biology of Ostracoda its fundamentals and applications. Kodansha Ltd, Tokyo, 413-428.

Boomer, I. 1993. Ostracoda (Crustacea) and the death of the Aral Sea. Geology Today, 9 (1): 18-22.

Boomer, I., Whatley, R. \& Aladin, N.V. 1996. Aral Sea Ostracoda as environmental indicators. Lethaia, 28: 77-85.

Corsi, S.R., Booth, N.L. \& Hall, D.W. 2001. Aircraft and runway de-icers at Great Mitchell International Airport, Milwaukee, Wisconsin, USA. 1. Biochemical oxygen demand and dissolved oxygen in receiving streams. Environmental Toxicology and Chemistry, 20: 1474-1482.

Croft, P.S. 1986. A key to the major groups of British freshwater invertebrates. Field Studies, 6: 531-579.

Curry, B.B. 1999. An environmental tolerance index for ostracodes as indicators of physical and chemical factors in aquatic habitats. Palaeogeography, Palaeoclimatology, Palaeoecology, 148: 51-63.

Davis, P.S., Seager, J. \& Milne, I. 1995. The impact of Combined Sewer Overflow Discharges on the Biological and Chemical Quality of Receiving Streams: Two Case studies from the Northwest of England. In: Herricks, E.E. \& Jenkins, J.R. (Eds), Stormwater Runoff and Receiving Systems Impact, monitoring and Assessment. Lewis Publishers, Boca Raton, USA, 163-176.

Eagar, S.H. 1999. Distribution of Ostracoda around a coastal sewer outfall: a case study from Wellington, New Zealand. Journal of the Royal Society of New Zealand, 29: 257-264.

Eagar, S.H. 2000. Ostracoda in detection of sewage discharge on a Pacific Atoll. In: Martin, R.E. (Ed.), Environmental Micropaleontology: The Application of Microfossils to Environmental Geology. Kluwer Academic, London, 151-163.

Environment Agency. 2006. Water Quality. Available online at: http:// www.environment-agency.gov.uk/subjects/waterquality. Accessed 16 February 2006.

Forester, R.M., Smith, A.J., Palmer, D.F. \& Curry, B.B. 2005. North American Non-Marine Ostracode Database Version 1 "NANODe". Available online at http://www.kent.edu/nanode. Accessed 7 March 2006.

Hazelton, C. 1998. Variations between continuous and spot sampling techniques in monitoring river-water quality. Water and Environmental Management, 12: 124-130.

Horne, D.J., Baltanàs, A. \& Paris, G. 1998. Geographical distribution of reproductive modes in living non-marine ostracods. In: Martens, K. (Ed.), Sex and Parthenogenesis: Evolutionary Ecology of Reproductive Modes in Non-marine Ostracods. Backhuys Publishers, Leiden, 77-99.

Margalef, R. 1953. Los crustáceos de las aguas continentales ibéricas. Biología de las aguas continentales, 10: 1-234.

Mason, C.F. 1996. Biology of Freshwater Pollution, (3rd edn) Longman, Harlow, 356pp.

Meisch, C. 2000. Freshwater Ostracoda of Western and Central Europe. In: Schwoerbel, J. \& Zwick, P. (Eds), Süsswasserfauna von Mitteleuropa 8/3. Spektrum Akademischer Verlag, Heidelberg.

Mezquita, F., Hernandez, R. \& Rueda, J. 1999. Ecology and distribution of ostracods in a polluted Mediterranean river. Palaeogeography, Palaeoclimatology, Palaeoecology, 148: 87-103.

Rosenfeld, A., Ortal, R. \& Honigstein, A. 2000. Ostracodes as indicators of river pollution in Northern Israel. In: Martin, R.E. (Ed.), Environmental Micropaleontology: The Application of Microfossils to Environmental Geology. Kluwer Academic, New York, 167-180.

Ruiz, F., Gonzalez-Regalado, M.L., Baceta, J.I. \& Munoz, J.M. 2000. Comparative ecological analysis of the ostracod faunas from low- and high-polluted southwestern Spanish estuaries: a multivariate approach. Marine Micropaleontology, 40: 345-376.

Samir, A.M. 2000. The response of benthic foraminifera and ostracods to various pollution sources: a study from two lagoons in Egypt. Journal of Foraminiferal Research, 30 (2): 83-98.

Schornikov, E.I. 2000a. Ostracod fauna from the East Sea Coast of Korea and their distribution - Preliminary study on Ostracoda as an indicator of water pollution. Journal of the Geological Society of Korea, 36 (4): 435-472.

Schornikov, E.I. 2000b. Ostracoda as indicators of conditions and dynamics of water ecosystems. In: Martin, R.E. (Ed.), Environmental 
Pollution indicators - freshwater ostracods

Micropalaeontology: The Application of Microfossils to Environmental Geology. Kluwer, New York, 181-187.

Seager, J. \& Abrahams, R.G. 1990. The impact of storm sewage discharges on the ecology of a small urban river. Water Science Technology, 22: 163-171.

Turnbull, D.A. \& Bevan, J.R. 1994. Integrated water quality monitoring: the case of the Ouseburn, Newcastle upon Tyne. In: Kirby, C. \& White, W. (Eds), Integrated River Basin Development. Wiley, Chichester, 325-338.

Turnbull, D.A. \& Bevan, J.R. 1995. The impact of airport de-icing on a river: the case of the Ouseburn. Newcastle upon Tyne. Environmental Pollution, 88: 321-332.
Wright, J.F., Furse, M.T. \& Moss, D. 1998. River classification using invertebrates: RIVPACS application. Aquatic Conservation: Marine and Freshwater Ecosystems, 8: 617-631.

Yasuhara, M., Yamazaki, H., Irizuki, T. \& Yoshikawa, S. 2003. Temporal changes of ostracode assemblages and anthropogenic pollution during the last 100 years, in sediment cores from Hiroshima Bay, Japan. The Holocene, 13 (4): 527-536.

Younger, P.L. 1995. Hydrogeochemistry of minewaters flowing from abandoned coal workings in County Durham. Quarterly Journal of Engineering Geology, 28: 101-113. 